University of Louisville

ThinkIR: The University of Louisville's Institutional Repository

Electronic Theses and Dissertations

$1-1925$

\title{
John Donne the preacher.
}

Dick Houston Hall

University of Louisville

Follow this and additional works at: https://ir.library.louisville.edu/etd

\section{Recommended Citation}

Hall, Dick Houston, "John Donne the preacher." (1925). Electronic Theses and Dissertations. Paper 561. https://doi.org/10.18297/etd/561

This Master's Thesis is brought to you for free and open access by ThinkIR: The University of Louisville's Institutional Repository. It has been accepted for inclusion in Electronic Theses and Dissertations by an authorized administrator of ThinkIR: The University of Louisville's Institutional Repository. This title appears here courtesy of the author, who has retained all other copyrights. For more information, please contact thinkir@louisville.edu. 


\title{
UNIVERSITY OF IOUISVIITE
}

- JOHN DONNE THE PREACHER-

\author{
A Dissertation \\ Submitted to the Faculty \\ Of the Graduate School of Arts and Sciences \\ In Partia.l Fulfillment of the \\ Requirements for the Degree \\ Of Master of Arts
}

Department of Engl1sh

By

Dick Houston Hall, Jr.

1925 
- JOHN DONNE THE PREACHER-

11641 
DEDICATION

\author{
TO \\ My Father \\ Whose Sound Sense \\ And Great Industry \\ Have Ever Been \\ My Pride And \\ Inspiration
}


TABIE OF CONTENTS 


\section{CONTENTS}

Chaptex

Page

I. A Sketch of the Life of Donne. . . . . . . I

II. Donne's Theological Studies and Convictions. 17 III. The Mechanics of Donne's Sermons... . . 31 IV. Points of Emphasis in Donne's Freaching. . 44

V. Donne's Place as a Preacher. . . . . . . 58

VI. Donne's Place in Iiterature. . . . . . . 72 Bibliography . . . . . . . . . . 85 
CHAPTER I

A SKETCH OF THE IIFE OF DONNE 


\section{CHAPTER I}

\section{A SKETCH OF THE IIFE OF DONNE}

In the year 1573 when Shakespeare and Marlowe were a.lready boys of nine, Chapman in adolescence, Spenser, Lyly and Richard Hooker men of twenty, John Donne, then important to only a few but destined to the company of royalty, was born.

Walton says, in his very excellent but inadequate and often inaccurate "Iives of Dr. John Donne, etc.," that his father was descended "from an ancient and worthy family in Wales." Gosse, however, calls this simply "a pious wish" because nothing is known of his father's parentage. He was a prosperous iron merchant of London, who died in 1576 leaving his family in very comfortable circumstances.

The poet's mother's great-grandmother was a sister to Sir Thomas More, sometime Lord Chancellor of England. She maintained her Catholic faith, as had her family ever since the days of Henry VIII, all her life. Her family had been persecuted more than once for fidelity to Rome and in his preface to Pseudo Martyr John Donne asserts that his own family had seen as great persecution as any of the same size and posi- 
tion in England. In 1593 Henry Donne, a younger brother of John, died of a fever which he contracted while in prison for having concealed a Jesuit priest in his room.

John was given the first part of his education under a private tutor in his father's house. When ten years of age he was sent to Oxford. After four years there he went to Trinity College, Cambridge, where he stayed until his seventeenth year. He was a good student and worthy of degrees, but his Catholic inclinations prevented his taking the oath required of those receiving degrees at that time.

The years 1590 to 1601 were given nominally to the study of law, but Donne actually studied many things. In 1591, then only eighteen years of age, he sat for a portrait in soldier's garb; probably before 1596 he had spent some time in Italy and Spain where he had learned both languages; in 1596 he saw service in the battle of Cadiz with the Earl of Essex when the Spanish fleet was defeated; and in 1598 he became secretary to Lord Thomas Egerton, then Lord Keeper of the Seal who later became Lord High Chancellor under James I, which position he held until he was discharged at the demand of an irate father-in-law. These were his best years as a lyrical poet if we accept Ben Johnson's words to Drummond of 
Hawthornden that he had written "All his best pieces ere he was twenty-five years old." As to his religious inclinations durine this period $\mathrm{Craik}^{l}$ holds that in 1592 he definitely cast "his lot with the English Church, but it was long before he took orders." It is true that Donne was studying the ology but Craik is mistaken about his having embraced the Anglican faith by this time because Walton, ${ }^{2}$ speaking of the time after 1591, says that Donne "had betrothed himself to no religion that mi ght give him any other denomination than a christian. And reason and piety had both persuaded him that there could be no such sin as Schism, if an adherence to some visible church were not necessary." "Reason" surely was much in evidence but when one reads his poetry of this period and faces his reckless days of lax living, the word "piety" is given less acceptance. Gosse must be correct when he says that "As soon as Donne found himself free from his mother's tutelage his attachment to the Catholic faith began to decline. Presently his indifference to its practice, combined with an intellectual scepticism as to its tenets, led him away from any Christian communion, yet all the while

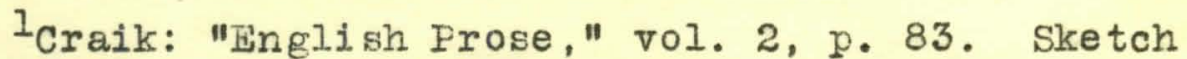
of life by George Saintsbury.

Walton: "Lives of Dr. John Donne, etc.," London 1898. p. I.1. 
he nourished a kind of dormant religiosity, ready to break forth into flame as soon as the tumult of the senses and the enraged curiosity of life had been somewhat assuaged by experience. Inwardly the seed of spiritual life was healthy, and was biding its time for expansion; externally, we may picture John Donne, from 1590 to 1600 , as leading a life of fair propriety in action perhaps, but one in which religion and sanctity of purpose could not be suspected. by the closest observer." 1

While secretary to Lord Egerton, Donne won his employer's favor to the extent that he enjoyed the hospitality of his home. Another member of the household was Anne More, niece to Lady Igerton and daughter to Sir George More, Cancellor of the Garter and Lieutenant of the Tower. A mutual regard arose between the two young people, and after Lady Egerton's death, while Anne acted as mistress of the house, greater opportunities to be together brought about the natural thing for kindred souls. When Lord Egerton decided to marry again and it was known that Anne would no longer be a member of the household, desperate plans were made which resulted in their mar27 f.

${ }_{\text {Gosse: }}$ Life and Letters of John Donne," $\nabla .1, p$. 
riage on the 5 th of December 1601. When Sir George heard of his daughter's marriage he was so enraged that he persuaded Lord Egerton to dismiss Donne from his services, and secured his imprisonment on the ground of violation of civil and canon laws. He was soon released from prison, but it was some time before Donne was able to get his wife from her father's house.

His habits of extravagance and his troubles, together with the loss of his position, had by this time reduced his exchequer to an embarrassing state. Sir George's forgiveness was finally obtained (Gosse gives some interesting letters of Donne's to his father-in-law about this time), and he tried to secure his re-instatement with Lord Egerton, but was unsuccessful. When he gave the devoted couple his blessing, Sir George neglected the material variety, and Donne, now twenty-nine years of age, found himself with greatly added responsibilities, but without either money or employment.

During the year 1602, however, a cousin of Mrs. Donne's, Sir Francis Wooley, came of age, and immediately invited the Donnes to make Pyrford the ir temporary home. The years that immediately follow are largely blank to us, but in 1605 we find him living a.t Mitcham, having moved away from Pyrford in or- 
der to be nearer to London, and possibly for other reasons as well.

Donne's rash marriage blasted his hopes of political preferment, and now we find that he resumed his theological studies, having already digested, as he says, 'the whole body of divinity, controverted between ours and the Roman Church.' In 1605 he assisted Dr. Thomas Morton in his controversies with the Roman Catholic writers. During their work together Dr. Morton tried to persuade Donne to take orders and offered him a living from his ow estates, but Donne declined the offer, not yet ready to accept such a calling, partly, I believe, because of hope of court preferment, but chiefly from a sense of unworthiness.

Nothing came from his court schemes and with very small if any income, he was often in great need. His position was anomalous. At thirty-four years of age, while "one of the most learned of living Englishmen in the law, he was not a lawyer; a profound theologian, he was not in orders; with a throng of exalted relations and friends, he possessed no post at court."I

These were the most trying years of his life. Sickness and death were frequent visitors in his

IGosse: "Life and Letters of John Donne," v. I, p. 155 . 
home and poverty was a member of the family. In a letter written in the fall of 1608 he bewails his own condition: "If it be gout, I am miserable; for that affects dangerous parts, as my neck and breast, and (I think fearfully) my stomach, but it will not kill me yet; I shall be in this world, like a porter in a great house, ever nearest the door but seldom abroad; I shall have many things to make me weary, and yet not get leave to be gone." I In a letter to Lord Hay which Gosse (vol. 1, p. 203) places at about the end of this period he hopes for "that place in Ireland" but fails to receive it.

Surely a man who had an open door to instant relief from his position of abject poverty and want, by accepting urgent offers to take orders-and with all other avenues of relief closed for over three years-would have accepted this means of relieving his family and himself had he not had very high ideals for the ministry and a determination not to enter so high a profession for purely mercenary reasons !

It was likely in 1608 that Donne wrote his second prose work, "Biathanatos," in which he deals with "selfhomicide." Gosse is sure that Donne, because of his

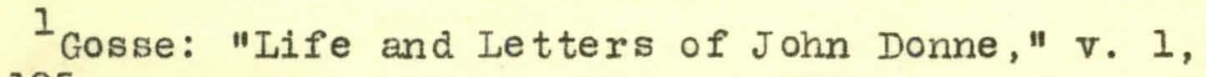
p. 195 . 
own wretched condition often entertained thoughts of suicide, and was here trying to excuse himself if he should some day yield to that temptation. He goes on to say: "If this is not the purpose and aim of Biathanatos, then it appears to me the idlest trifling with the dry bones of disputation that was ever committed." I In this book which he afterward forbade to be published or burned, Donne defends suicide with such clever reasoning that his friends could not discover his fallacy, and he admits in the preface that "whensoever any affliction assails me, methinks I have the keys of my prison in my own hand, and no remedy presents itself so soon to my heart as mine own sword."

This threat seems to have urged Sir Francis Wooley to persuade Sir George More to pay to the Donnes, as Mrs. Donne's dowry, 1800 , \pm 20 to be paid quarterly till the principal was retired. This gave Donne a very good income and elevated his spirits. He could now afford the dress that custom required of those who appeared at court, and we find him still hoping for preferment. In 1609 he says in a letter that 'John Donne seeks to be Secretary at Virginia.' In 1609 he wrote his "Pseudo Martyr," at the re$1_{\text {Gosse, v. 1, p. } 263 .}$ 
quest of the King, the book being published in 1610 . This was the first of his prose works to be printed. In this book he argues against the attitude of Catholics towards the oath of allegiance.

On the 17 th of April 1610, Donne received the honorary degree of Master of Arts from the University of Oxford, being allowed to receive the degree without the preliminary B. A.

From 1610 to about 1612, while in the home of Sir Robert Drury, Donne seems to have abandoned the study of theology. He had written a funeral elegy on the death of Elizabeth Drury, Sir Robert's only child, and was immediately taken into his patronage and given a rent-free house in Drury-lane. In 1612 he was in Paris wi th the Drury's, returning to London about the first of september of that year. Gosse dates a letter in October 1612 (vol. 2, p. 21) in which Donne introduces himself to Lord Rochester, and, probably for the first time, declares his intention to make divinity his profession. Gosse thinks that Rochester discouraged Donne's resolution by holding out further hopes of success at court. At any rate, nothing more is said about it, so far as our records go, until three years later.

The year 1613 was spent in impatient waiting for 'something to turn up' his wife's allowance supplying 
the necessities of life. But 1614 was one of the darkest years of his life. One child, Mary, died in May, and Donne himself had a very serious illness. Gosse says: "He was ambitious, he was eager to be independent, he was justly confident in his marvellous powers, and yet at the age of forty, Donne, perhaps the most brilliantly equipped mind in his Majesty's dominions, was a nobody and a nothing still."1 A realization of these facts added to his other troubles brought Donne to the point of desperation. About this time rumors began to go about of the instability of Rochester (now Somerset) and Donne became frantic lest all his hopes should miscarry. He went to somerset in November 1614 and Somerset, at his demand, went at once to the King to try to secure an appointment for him. This the King denied him saying: "I know $M r$. Donne is a learned man, has the abilities of a learned divine, and will prove a successful preacher; and my desire is to prefer him in that way, and in that way I will deny you nothing for him." 2

Somerset then brought Donne into the King's presence and "the King 'descended to a persuasion, almost to a solicitation of him, to enter into sa-

\footnotetext{
${ }^{1}$ Gosse: "Life and Letters of John Donne," vol. 2,

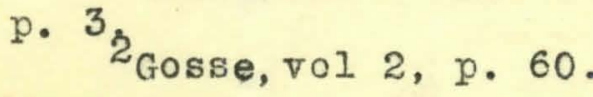


cred orders."I After a few days for consideration, Donne decided to accept the King's counsel and began to prepare himself for the ordination, which, according to Dr. Jessop's conjecture, took place on the 25 th of January, 1615.

On April 7 th following, Donne was given the degree of D. D. by the University of Cambridge. Gosse 2 shows that this was done at the King's cormand and with no little reluctance by the authorities of the University.

As a preacher Donne met with immediate success. Walton tells us that he even went beyond what was expected of him in his first sermon.

In October 1616, Donne was appointed Divinity Reader to the Benchers of Iincoln's Inn, and during the year he also was presented with two country livings.

"In March 1617, Donne was appointed to preach in the famous open-air pulpit of Iondon at Paul's Cross, before the Lords of the Council and the City Magistrates. . . Donne on his first appearance in this open-air pulpit preached a sermon of enormous length,

\footnotetext{
${ }^{1}$ Gosse, vol. 2, p. 60.

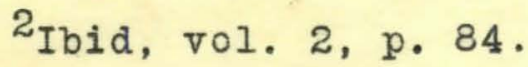


which, if delivered as printed, must have kept his audience standing for at least two hours. ${ }^{1}$ It was, however, in contemporary opinion 'a dainty sermon,' and was 'exceedingly well liked' especially for the praise he gave to Queen Elizabeth." 2

In August 1617 Donne's wife died, leaving him seven children to care for. This was God's final act in the preparation of His servant for His work. Donne promised his children that they should never have a step-mother, and he remained true to his promise. The shock was great, but he became the more devoted to his calling rather than rebellious at God's dealings. "It was the loss of his wife which brought about the final process of sanctification and illumination. . . The morbid strain in Donne's temperament asserted itself at first, as it often does in such cases. He shrank from all communication with his friends; he nursed his grief by staying at home in solitary despair, or by darkening with his presence the group of his motherless children." ${ }^{3}$ But soon Donne had overcome the shock of his loss and a new day began to dawn, a day of spiritual devotion

$l_{\text {Gosse estimates that this sermon required two }}$ hourg and forty minutes for delivery.

3 "Donne's Sermons," Pearsall smith, Int. xliii.

3 Gosse, vol. 2, p. 101. 
and power that he himself had not known and that his generation had not seen before. His mind and energy had been dedicated to God before, now the process was completed by a heart and soul set on fire for his Saviour. What $h$ ad been more or less a profession now became a passion with Donne, and he became as Walton says: "Crucified to the world," and all the worldly things that had attracted him were "crucified to him." In 1619 , Donne's physical condition being very poor, he was sent with Lord Doncaster on a mission to Germany. This trip lasted from May 1619 until January 1620 and it was the thing that Donne needed to put him on his feet again. His premonitions as to his approaching death seem to have been forgotten on this trip, as we have no mention of his malady in his letters. We have in print one of the two sermons he preached before the Electress Palatine and a sermon that he preached at the Hague while on this trip. The latter sermon he afterwards enlarged into two sermons.

In November 1621, Donne was duly elected Dean of St. Pauls, the King having "carved" to him this "dish" at a dinner to which he had invited him. He preached his first sermon in the cathedral on Christmas Day, 1621. His Christmas sermons, which he preached at St. Paul's every year thereafter except 
at the end of his life have been preserved, as have also his Easter Day and Whitsunday and other sermons on special occasions.

February 11, 1622 he resigned his Preachership at Iincoln's Inn and reluctantly took leave of his friends who had known and loved him both as Jack Donne and as Dr. Donne, in all that the two names signified.

In October 1623 he had a very serious attack of the disease which finally caused his death, and for some time his life was despaired of. During his long convalescence he wrote his "Devotions," which volume was published in 1624 .

The plague drove him out of his beloved London in 1625 and he took refuge with his old friend Magdalen Herbert, George Herbert's mother, who was now Lady John Danvers, living in the village of Chelsea.

During the last few years of Donne's life there are few things of importance to relate. He preached before the new King, Charles I, in April 1625, the sermon being printed at once. In the summer of 1630 Charles I planned to promote him to the prelacy, but his complete and final breakdown in heilth prevented his ever receiving a bishopric.

On the 12th of February, 1631, Donne preached his last sermon. He was in a very frail condition, not 
really able to stand in the pulpit, as Walton tells us, but he was determined to keep his customary appointment to preach at this time before the King at Whitehall. His text was: 'To God the Lord belong the issues from death,' and to his audience he was preaching his ow funeral sermon. Soon after his death this sermon was published as "Death's Duel."

Before his death, having been "easily persuaded" to leave a monument to himself in the Cathedral, Donne had himself wrapped in a sheet which was, as Walton says, "So tied with knots at his head and feet, and his hands so placed as dead bodies are usually fitted to be shrouded and put into their coffin or grave."I And, standing upon an urn with his eyes closed and his face "purposely turned toward the east," he had a picture painted from which a statue was later modeled. This statue may be seen to-day in St. Paul's Cathedral.

Having completed all his arrangements for the departure, Donne patiently waited. On the 3 lst day of March he passed away with the se last words: "Thy kingdom come, Thy will be done."

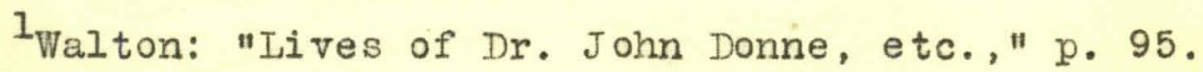


CHAPTER II

DONNE'S THEOLOGICAL STUDIES AND CONVICTIONS 


\section{CHAPTER II \\ DONNE'S THEOLOGICAI STUDIES AND CONVICTIONS}

A few years before Donne was born Queen Elizabeth was formally excommunicated, and her subjects were absolved from allegiance to her, by the Pope, because she refused either to acknowledge his supremacy or to heed his appeals for relief to Catholic communicants who refused to join the English Church.

A number of Donne's relatives moved away from Ingland because of these persecutions. Two of his maternal uncles were Jesuit priests and there were many prisoners and exiles for the Roman faith in his family. In the preceding chapter I have spoken of Donne's cognizance of the se facts in the preface to his "Pseudo Martyr."

It is but natural to think that his early prejudices were in favor of the Catholic Church. His early training was surely in strict conformity to that religion and when he was ready to be graduated from Cambridge, he refused to take the necessary oath and sacrificed his degree in maintaining his own or his family's Catholicism. 
In 1592 we find him admitted to Lincoln's Inn, having been in London since 1590. He was capable and ambitious but, as a Roman Catholic, he could have no hopes of any great worldly success. Before deciding the matter he read and digested, as he says, 'the whole body of divinity, controverted between ours and the Roman Church,' and Mr. Smithl explains his change from Catholicism as hardly "due to a genuine conversion to Anglicanism, or to any belief that it was alone the true church, (but) it does not appear on the other hand to have been a mere apostasy prompted by political considerations. Donne was genuinely convinced that there was truth in each form of the Christian religion, and that it was wisest and best for each man to accept the faith of his own country."

It seems certain, however, that this change did not come very suddenly. There seem to have been some years in which no "other denomination than a Christian," if that indeed, could be assigned to him.

Gosse 2 thinks that the reason why Donne refused to accept Morton's offer in 1605 was that he was still attached to the Roman Church, but Mrs. Simpson ${ }^{3}$ re-

1Smith: "Donne's Sermons," Int. p. xl.

"Iife and Letters of John Donne, " v. 1, p. $161 \mathrm{f}$.

E. M. Simpson: "A Study of the Prose Works of John Donne," Onford 1924,p. 25. 
veals the fallacy in this argument by showing that Donne had won Morton's approval by his work in opposing Romanists beliefs, he having worked with Morton for some time on the subject. In speaking of "The Progress of the Soul" written in 1601, Gosse ${ }^{1}$ says that "he had lost his traditional faith as a Catholic and no light had come to him from the other church." He seems to have forgotten this argument when considering his life four years later. The first time that we have record of Donne's referring to himself as a member of the Anglican church is in a letter which Gosse places about July, 1607, because of a reference to a visit of "the French Prince" whom he is sure is Prince de Joinville, who visited England in June, 1607. In this letter Donne speaks of "continence in the Roman Church, and or der and decency in ours." 2

The fact that he had not mentioned his change before is not proof that he was still in the Roman Church. I am convinced, from the arguments given above, that he was not in the Roman Church, but was surely neutral, and I believe that he was more than likely in the English Church by 1605. Morton would naturally have known of his family's religious be-

$1^{\prime \prime L i f e ~ a n d ~ L e t t e r s ~ o f ~ J o h n ~ D o n n e, " ~ v o l . ~ 1, ~ p . ~} 140$. Ibid, vol. 1 , p. 170 . 
liefs and he would have hardly employed, much less importuned to take orders, a man who was even neutral in his beliefs. There would have been some question as to his own convi ctions had Morton done so.

Donne seems to have had a natural bent to theology. That he was independent in his thinking is shown by the fact that he early began to study for himself the conflicting positions of the two churches, and formed his own conclusions in spite of family prejudices. The study of theology must have begun as a hobby with him, as some hold, and yet I believe that there was all the time an inward urge that Donne would have refused to admit even to himself: that consciousness of a call of God to preach the Gospel.

Some of his students think that Donne only accepted orders when every other avenue to success had been definitely closed to him, and then only for the sake of a livelihood, but I cannot fully accept this position. There were periods of indifference to and rebellion from this call of God, to be sure, and Donne did not accept it until he was shown that he could not succeed in other lines, but the se things only strengthen my belief that he fought against what he believed to be the will of God from the time of his early manhood until he accepted orders. He was a man of extremes, and one can probably better understand his 
reckless living and his sensuous poetry if Donne is considered as one who is conscious of a God-given mission which is distasteful to him, and who is trying to unfit himself for that mission by violating his ideals for it. Gosse speaks of his nourishing "a kind of dormant religiosity, ready to break forth into flame as soon as the turnult of the senses and the enraged curiosity of life had been somewhat assuaged by experience."I

Donne's early life was spent in a devout home. As soon as he left that home, he began to study the differences in the conflicting faiths of the day. Because of his position there came a period of recklessness in which he tried to find satisfaction in travel, in soldiering, and in the gay society of his time, but he was not satisfied. His was a melancholy temperament that caused him to have periods of depression. His friends naturally attributed these things to outward conditions, but there may have been a deeper reason for such a disposition. He ventured into the field of poetry, but there is no evidence that he mixed with the literary men of the day as one who chose to gain fame by letters would naturally do. For a while the hobby became a serious business with him, but he never gave it the whole-heartedness

Gosse: "Iife and Letters of John Donne," v. 1, p. 27 (see above p. 5). 
characteristic of Dr. Donne of later years. All this time he was seeking court preferment, probably trying to secure an easy living without having to consider conscience, rather leaving the responsibility of his vocation, except for preaching, with the King. His own high regard for the ministry and the feeling that his life had been unworthy of so high a calling, were shown when he refused to accept offers, even when he was in abject poverty, and such acceptance would have instantly relieved his needs. These facts and the added fact of his immediate and lasting success and happiness after he did take orders, argue conclusively to me that Donne felt and fought a call to preach, from the early years of his life. And, tracing the outstanding events of his life, we can see that Donne fought a losing battle against a Providence who was determined to use him as a chosen vessel. That he did not inherit his father's abilities as a financier may be seen in the facts that his supposedly handsome inheritance was soon spent and that he had saved no money from his position with Lord Egerton when he was thrown out of employment. In 1601 he lost his position and was disgraced. The period from 1602 to about 1610 was one of great embarrassment, for he was almost entirely dependent on his friends for the support of himself and his growing family, and be- 
sides this, sickness and death came often to visit his home. In 1605 he declined Morton's offer and in 1610, when his "Pseudo Martyr" gave him an auspicious opportunity for success in orders, he still refused. Flashes of hope for court preferment continued to come to him and, with equal regularity, to go. In 1612, despairing of his worldly ambition, he decided (this time voluntarily) to gi ve heed to the 'still small voice,' and he declared his intention to Rochester by saying: "For having obeyed at last, after much debatement within me, the inspirations (as I hope) of the spirit of God, and resolved to make my profession Divinity; I make account that I do but tell your Lordship, what God hath told me, which is, that it is in this course, if in any, that my servic may be of use to this church and state."I This letter was sent in another 'To the Lord Hay,' who was to be the bearer of the former one, in which he said: "I have brought all my distractions together, and find them in a resolution of making divinity my profession, that I may try whether my poor studies, which have profited me nothing, may profit others in that course; in which also a fortune may be better made, or, at least bet-

${ }^{1}$ Gosse: "Life and Letters of John Donne," vol. 2, p. 20 . 
ter missed than in any other." 1 But he willingly, it seems, changed his mind when his patron advised. In spite of the mercenary note in the last sentence quoted, he had already said enough to convince us of his call to preach and at the same time that he was not ready to accept it. The year 1613 was the final mark of preparing him for, and bringing him to Himself. In the spring his seventh child, Mary, died and on the loth of November, Francis, his fourth son, was buried. Donne, himself, was slowly recovering from a threatened attack of blindness, and his general health was unsati sfactory. At last he was ready, ready to leave all and take up his cross and follow the christ. The battle on the inside had been lost and won and it only needed the word of his sovereign to make him follow the lord of all. And from that time forward there was no doubt in his, nor any other mind that John Donne was where he belonged.

As to his orthodoxy Smith says: 2 "He stated the main doctrines of the Inglish Church with such moderation and such learning, that a selection of passages from his sermons might make a useful volume of Anglican apologetics. . . Or again, taking

${ }^{1}$ Gosse: "Life and Letters of John Donne," vol. 2, p. $2 \mathrm{Q}$.

Smith: "John Donne's Sermons," p. xxiif. 
Donne as a representative mind of his period, one might use his sermons for illustrating the history of human thought, and by selecting typical pages from them give a picture, not only of the theological conceptions of the time, but of the philosophy then current, and the main ideas that were accepted by the cultivated men of that period." "Whatever doubts," says the Cambridge History of English Iiterature, ${ }^{1}$ "may, at times, have agitated his secret thoughts, or found expression in an unpublished sonnet, they left no reflection in his sermons. He adopted and defended the doctrines of the Church of England, and the policy in church and state of her rulers, in their entirety and without demur."

He was not intolerant of those who held other theological views than his. Iikely the fact that he reached his religious convictions through mature and thorough study, rather than by accepting the teachings of his childhood or the propositions of others, accounts for his rare spirit of fairness in that time when religious wars were rife. He adopted a policy which few are happy enough to follow even to-day in the lines:

"To adore or scorn an image, or protest, May all be bad; doubt wisely; in strange way

$I_{\text {Vol. IV, p. } 234 .}$ 
To stand inquiring right, is not to stray;

To sleep or run wrong is. On a huge hill,

Cragged and steep, Truth stands, and he that will

Reach her, about must and about must go;

And what the hills suddenness resists win so."

Iynd says that "this surely was the heresy of an inquisitive mind, not the mood of a theologian. It betrays a tolerance springing from ardent doubt, not from ardent faith." I am inclined to take issue with this statement. Donne's "Pseudo Martyr" and "I gnatius his Conclave" as well as the soundness of doctrine in his sermons, give us no room to doubt his orthodoxy, but this rather gives us a glimpse of the fairness of the man, a fairness doubtless fostered by his own peculiar experiences, and one which is pleasing to find in that age of theological prejudices. "He preached toleration in an age which demanded rigid conformity and his controversial sermons lacked the bitterness which was demanded of a zealous defender of the faith. The Puritans suspected him of an inclination to Popery, while Laud's party at one time thought him in league with the Puritans." 2

Mrs. Simpson offers this characteristic as the

1"The Art of Letters," Robert Lynd 1921, p. 132.

2E. II. Simpson: "A Study of the Prose and Works of John Donne," p. 67. 
reason why Donne was not given the place of prominence in their church which he surely deserved.

In 1617 the same spirit of open-mindedness is seen in the lines:

"Show me, dear Christ, Thy Spouse so bright and clear.

What? Is it she who on the other shore Goes richly painted? or who robb'd and tore Laments and mourns in Germany and here? Sleeps she a thousand, then peeps up one year?" "An examination of the 'Sermons,' "Mrs. Simpson says, 1 "shows that there was nothing very heterodox in Donne's mature opinions. In his youth he had propounded certain heretical views on such doctrines as the transmigration of souls ("The Progress of the Soul," begun and abandoned while in the home of Sir Thomas Egerton) and the nature of woman. In the 'Sermons' he retracts these opinions, and there is no evidence to prove that he had ever held them seriously or had regerded such subjects as anything but stalking-horses for the display of his youthful wit."

Donne denied such doctrines as transubstantiation; he did believe that the faithful receive the body and blood of Christ, but that the church does not accom-

"A Study of the Prose Works of John Donne," p. 67. 
plish this thing. He did not consider prayers for the dead as necessary, nor did he believe that unbaptized infants are condemned to hell.

"His theology was sometimes illogical but perhaps it was none the worse for that. The attempt to treat man's knowledge of God as an exact science has led to countless troubles in religion. Donne was content to own that life is full of unsolved mysteries, while basing his faith on a God 'whose judgments may be unsearchable, but they cannot be unjust.'"l

Again Mrs. Simpson says: 2 "His attitude towards the Christian falth is not that of the professed theologian carefully building up an edifice in which every dogma has its place and which may be endangered by the removal of a single article of belief. He is rather the poet who grasps certain great ideas by intuition, not by logical reasoning, though in the framework with which he surrounds them he may call in the aid of the discursive intellect."

Surely such intellectual powers, such cultivation by fiery trial and such a surrender to the call, together with such a spirit of humility and devotion,

${ }^{1}$ Simpson: "A Study of the Prose Works of John Donne, " p. 59. Ibid, p. 68 . 
adequately prepared Donne for his rightful place as the leading divine of his day. 


\section{CHAPTER III}

THE MECHANICS OF DONDE'S SERMONS 


\section{CHAPTER III}

\section{THE MECHANICS OF DONNE'S SERMONS}

Of Donne's sermons there are more than 160 available to-day. Alford gives 157 in his "The Works of John Donne, D. D.," Mrs. Simpson in her recent work gives a semon on Psalm 38:9, which has never been published before, and there are several other sermons published which have not been available to me.

The texts of these sermons are taken from 36 of the 66 books of the Bible, 80 of them being from the New Testament. Thirty-three of his texts are from the Psalms. "The Psalms," he said, " "are the manna of the Church. As manna tasted to every man like that he liked best, so do the Psalms minister instruction, and sati sfaction to every man in every emergency."

There are 16 sermons on texts taken from Matthew and 15 on texts from John, 9 from Genesis and 8 from

I"The Second of My Prebend Semons Upon My Five Psalms" Preached at St. Faul's, January 29, 1625. Alford, "The Works of John Donne, D. D.," vol. III, p. 156. (Alford or Donne or an intermediary has made a mistake in this date or in the date of the "First Prebend Sermon," which is dated May 8, 1625). (Ibid p. 135$)$. 
I Corinthians.

Donne often preached more than once on the same text. In Alford's list there are two sermons given on each of 10 texts. In every instance where the place of preaching is shown, the sermons were preached at the same place, once both sermons were preached on the same day, April 19, 1618, at Whitehall, on the text: "This is a faithful saying, and worthy of all acceptam tion, that Christ Jesus came into the world to save sinners; of which I am chiefest" (I Timothy 1:15). Of course it is possible that this was one sermon when Donne preached it, but when he came later to write it out he made it into two sermons, as it was in the case of a sermon on Matthew 4:18-20, preached at the Hague, December 19, 1619, and enlarged as he says "in my sickness at Abrey-hatch, in Essex, 1630, revising my short notes of that sermon, I digested them into these two." I

In three instances we have three sermons preached from the same text. At Lincoln's Inn, Donne preached three sermons on Psalm 38:4, "For mine iniquities are gone over my head, as a heavy burden, they are too heavy for me." At St. Faul's, on Easter Sunday 1626, May 21, 1626 and June 21, 1626, he preached on the 
same text: "Else, what shall they do which are baptized for the dead? if the dead rise not at all, why are they then baptized for the dead?" (I Corinthians 15:29). And again, within a year, Christmas day 1621, midsummer day 1622, and on the 13 th of October 1622, he preached three times at St. Paul's on John 1:8, "He was not that light but was sent to bear witness of that light."

Dr. John A. Broadus ${ }^{l}$ divides sermons into three different species, namely, subject-semons, text-sermons, and expository sermons. "Subject-sermons," he says, "are those in which the divi sions are derived from the subject, independently of the text; while in text-sermons, the divisions are taken from the text."2 "An expository discourse may be defined as one which is occupied mainly, or at any rate largely, with the exposition of Scripture." 3

Of course no set of rules $c$ an be given by which every sermon can be definite ly classified, but generally a sermon can be placed into one of these classes. In our day, when sermons are generally much shorter than in Donne's, these rules may be more applicable, because in reading Donne's sermons we find that he often gave a very thoraugh exposition of his text, then

Tlepreparation and Delivery of Sermons," pp. 306-38. Ibid, p. 307 .

3 Ibid, p. 322 . 
drew lessons from his text, and had time left to follow out the divisions of his subject, all by the time the sand had run out of the hour glass. (He is said to have limited himself to this time but very few of his sermons as we have them could have been delivered in so short a time. I am inclined to believe that in writing them out later, Donne added a good deal of the exegesis that we have-but this is only a guess). In classifying them, however, we may say that Donne preached sermons of all three species. We have an example of his expository preaching in the six sermons that we have on Psalm VI. ${ }^{l}$ And again, thereare eight sermons on Psalm XXXII. ${ }^{2}$ and yet these might be considered as text-sermons in another sense because Donne preaches each sermon using one or two verses as his text, and his divisions are largely drawn from the texts.

His sermons, like his poetry, do not follow definite rules, but have an individuality of their own. It seems to me, however, that Donne's sermons may be classified chiefly under the head of text-sermons. We have no record of his taking a book of the Bible and. preaching through it in expository sermons. None of his

lAlford: "The Works of John Donne, D. D.," vol. II, $\mathrm{gp}$. 375-501.

Ibid, vol. II, pp. 502-588 and vol. III, pp. I- . 
texts are over two or three verses long, whereas an expository sermon will often cover several verses or even a whole chapter.

But Donne did often preach what might be definitely considered a subject-sermon. On occasions like the "Anniversary Celebration of our Deliverance from the Powder Treason," Donne selected his text to fit his subject (Iamentations 4:20: "The breath of our nostrils, the anointed of the Lord, was taken in their pits."). And, while he gave consi derable time to the text, the divisions of his main message come from his subject.

Donne's famous Christmas, Easter, Whi tsunday and other occasional sermons are, as a rule, textual sermons. In these Donne selects appropriate texts and brings his messages from the se texts.

It is noticeable that in his Lincoln's Inn sermons, Donne, preaching to those who had known him in his days of impious living, struck a very strong evangelistic note, trying to bring his friends to repentance and salvation.

In preparing his sermons Donne seems to have made copious notes. The sermons that ve have were written after, rather than before, they were preached. In a

Alford: "The Works of John Donne, D. D.," vol. V, pp. 202-232, preached Nov. 5, 1622. 
letter to Sir Thomas Roe l Donne says that a sermon preached on Gunpowder Day "which also by commandment I did write after preaching, is as yet in his Majesty's hand, and I know not whether he will in it, as he did in the other, after his reading there of, command it to be printed;. . and whilst it is in that suspense, I know your Lordship would call it indiscretion to send out any copy there of; neither truly am I able to commit that fault, for I have no copy."

As to his habits of preparation, Mrs. Simpson ${ }^{2}$ has said: "He generally preached once a week, if not more often, and immediately after the delivery of one sermon, he would choose a text for the next, and plan out the heads under which he would consider the subject. During the week he would consult the Fathers and cast his study and meditation into suitable form. On Saturday he gave himself a rest, and visited his friends or otherwise diverted his thoughts, saying ' that he gave both his body and mind that refreshment, that he might be enabled to do the work of the day following, not faintly, but with courage and cheerfulness.'"

I do not know Mrs. Simpson's authority for the statement that "immediately after the delivery of one

IGosse: "Life and Ietters of John Donne," vol. 2, p. ${ }^{175}{ }_{\mathrm{Mrs}}$ of John Donne," p. $40 \mathrm{f}$. 
sermon, he would choose a text for the next," but I am inclined to doubt its accuracy. One who tries to preach, and I presume that Mrs. Simpson is not in the ministry, knows that of all times, immediately after preaching one sermon is the least suitable one for selecting a text for another. When a minister has delivered a sermon, his mind and body are both tired-especially would this be true of Donne with his frail body and his long discourses-and the natural thing to do would be to wait until he had had rest before selecting a text for, or thinking about the next semon. He had the wisdom to rest on Saturday in order to fit himself for Sunday's tasks, and surely he chose his texts with great care and at the time when he was most fit for study and meditation.

It is of interest to know that Charles Spurgeon, doubtless of equal fame as a preacher in his ow day, began his special preparation on Saturday evening before he was to preach on Sunday morning. He took a long time in deciding on his text, and then, after carefully studying the text in Greek or Hebrew or both, he made an outline, from which he delivered his sermon.

In his sermons, Donne made great use of authorities. His sermons are filled, of ten burdened, with quotations from the Fathers and others. Of these, Augustine 
is quoted most of all, then Jerome, Ambrose, Chrysostom, Gregory the Great, Origen and Tertullian. Of the mystical writers, Donne quoted'Dionysius Areopagiticus,' Gregory Nazianzen and Gregory of Nyssa (two of the famous "three Cappadocians"), Bernard of Clairvaux, the Schoolmen, and Aquinas and his followers. He also quoted the Roman theologians, Bellarmine and Cajetan, and the Reformers, Iuther and Calvin.

Donne's illustrative material, his metaphors and similes, are rarely from the ordinary sources. "Most of his comparisons in the sermons are drawn from circles, maps, engravings, elephants, whales, fleas, dis coveries in the West Indes, scholastic theories of the nature of angels, and so forth." 1 And Lynd 2 has brought out that "he did not go to the hills and springs for his images, but to the laboratory and the library, and in the library the books that he consulted. to the greatest effect were the works of men of science and learning, not the great poets with whom London may be said to have been peopled during his lifetime."

There is often to be found repetition in Donne's imagery, but this is natural for one who is constantly required to be making sermons. There is no falt to

1E. M. Simpson: "A Study of the Prose Works of John Donne, " p. 48. 2 "The Art of Letters, " p. 31. 
be found in his using the same figure in two sermons to different audiences. There are few, if any preachers to-day, or in any day, who would write or preach a hundred sermons without using some pet figure or illustration more than once.

Lynd ${ }^{l}$ remarks that "as a preacher, no less than as a poet, he is inflamed by the creative beat. He shows the same vehemence of fancy in the presence of the divine and infernal universe-a vehemence that prevents his most far-sought extravagances from disgusting us as do the luke-warm follies of the Euphuists. Undoubtedly the modern reader smiles when Donne, explaining that man can be an enemy of God as the mouse can be an enerny to the elephant, goes on to speak of 'God who is not only a multiplied elephant, millions of elephants multiplied into one, but a multiplied world, a multiplied all, all that can be conceived by us, infinite many times over; nay (if we may dare to say so) a multiplied God, a God that hath millions of the heathens' gods in Himself alone.'"

In reading Donne's sermons one is often startled by the most unexpected kind of an imaginative picture. Sometimes it is a picture of surpassing beauty, and again there is a conceit that surprises and repels us. His is truly "a grave digging 
imagination that is at home among the stars." l

Personal references are ri ght frequent in Donne's sermons. But he never speaks of himself in a laudam tory way. In pleading wi th his hearers he may refer to his own weakness or lack of faith or trust in and dependence on God, for the purpose of bringing lessons to them. Hence, this may be said to add to rather than detract from his style.

It is not a hard matter generally to follow Donne's outline in reading his sermons. His usual method is to give some space to the exegesis of his text, outlining it and giving the various translations and interpretations of $i t$, and then his own interpretation. Then he lays down his proposition and outlines the various heads under which he intends to discuss it. This outline is sometimes given in a very concise way, and again it is full e nough to be considered a discussion in itself. From this he launches out into his main argurnent under the heads outlined, of ten going so far afield that one is lost and wonders if he himself knows how to get back to the main trail, until suddenly he brings us out of the woods into a field of surpassing beauty and on to a worthy goal.

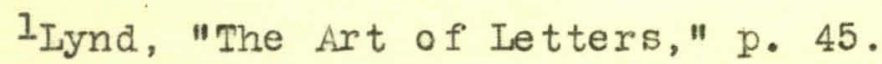


In interpreting Scripture, Donne seems to be a disciple of Augustine, who found allegorical meaning in almost every passage. For example, Augustine explains the 153 fishes caught ${ }^{l}$ by saying that "lo is the number of $1 \mathrm{zw}$. 7 equals the spirits spoken of by Isaiah. 10 plus 7 equals 17. Now add all the numbers, 1 to 17, and we have 153." From this he gœs on to show that by the addition of law and grace, we have the well rounded Christian life.2 Donne hardly goes so far in his allegorizing, but some of his explanations from the theological point of view of the text seem very far-fetched at times.

But Donne does not depend on this method exclusively in interpreting his texts. He often goes very carefully into the grammatical construction, proving points by verb constructions. For example, he shows that Christ's resurrection is different from that of people who were raised by Himself and others in the Scriptures, by the voice of "He is risen." The difference is that Christ had the power to raise Himself up. 3

IJohn 21:11.

2 Dr. A. Souter, Aberdeen University, Scotland. George W. Norton Foundation Lecturer at The Southern Baptist Theological Seminary, Louisville, Kentucky, December 11, 1924.

${ }^{3}$ IXXX Sermons, Number XXV, p. 249. 
Mrs. Simpson has brought out that in his appeal to authority and the development of syllogistic reasoning, Donne's method of argument was that of the Middle Ages. 1 She also shows that "his philosophy was a continuation of the $i$ deas of Augustine and Aquinas." I As to his style, Mrs. Simpson says: 2 "Donne's style is richer and more varied in the 'Sermons' than elsewhere. He is a master of the long paragraph, cunningly marshalling his clauses for the cumulative shock effect, as in the famous description of damnation (see Chap. IV, p.50 ff.), or the alrost equally famous passage on God's mercy. . . But the long period is not his only instrument. Scattered throughout the 'Semons' are felicitous short phrases which linger in the memory."

Donne's rule was to preach "his hour, and but an hour." He prepared notes which he took with him into the pulpit, and with the freedom that he thus had, he doubtless preached with more power than if he had been bound down by written discourses. And in his written sermons we have the advantage of both his previous preparation and the inspiration that comes with the delivery of a sermon.

${ }^{1}$ Simpson: "A Study of the Prose Works of John Donne, " p. 46. Ibid, p. 35 . 


\section{CHAPTER IV}

POINIS OF EMPHASIS IN DONNE'S

PREACHING 


\section{CHAPTER IV \\ POINTS OF EMPHASIS IN DONNE' S PREACHING}

It has been shown by Miss M. P. Ramsay in her "Les Doctrines Medievales chez Donne, le poete metaphysicien de I'Angleterre"l that "Donne's thought is marked by three characteristics-it is fundamentally theological, its attitude toward natural science and the knowledge of the external world is in hamony with that of the Middle Ages, and it as signs to authority a place very similar to that given to it by medieval times."

Miss Ramsay also hol ds that Donne's philosophy was largely Neoplatonic in character. 2 "It was through St. Augustine, Gregory of Nyssa, the pseudo-Dionysius, and other Christian sources that Neoplatonic ideas became familiar to Donne as to other theological students." His philosophy is incomplete and fragmentary. He did not write philosophical treatises nor did he compose a great philosophical poem. His metaphysical ideas pervade all his work but are not set forth as a definite

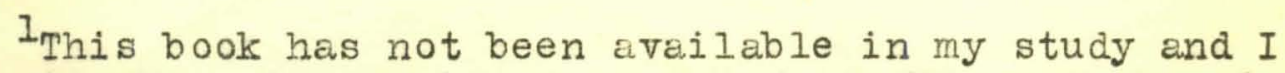
am using Mrs. Simpson's "A Study of the Frose Works of John Donne," p. 94, as authority for this statement. 2 Ibid, p. 90. 
system. Also his opinions changed in some important respects during his career.

"Donne's mysticism cannot be isolated from the rest of his thought," says Mrs. Simpson, 1 "for his whole philosophy is that of a Christian mystic reared in the Neoplatonic tradition which the scholestic writers of the Middle Ages had inherited."

He speculates a great deal on doctrines like original sin, angels, devils, election, predestination, and the relationship in the Trinity. He indulges in the sophistries of the schoolmen, such as the question whether the serpent had feet and walked upright before the fall.

In the personal elements in Donne's sermons, he has the happy faculty of holding himself on the same plane with his hearers, remembering that he, too, is subject to temptations in the same way as are his people. He does not forget, now that he is able to withstand temptations to gross sinfulness, that his life has not always been free from corruption and that but for his Saviour, it would still be evil. Nor can he set himself up even now as a model to follow. He is still unworthy of God's mercy and love, so preacher and people stand on the same footing before an infin-

$$
{ }^{\text {I Ibid, }} \text {. } 97 \text {. }
$$


ite God, and the one confesses to and pleads with the rest. Robert Iynd ${ }^{l}$ quotes the following passage from one of Donne's sermons, illustrating his use of personal references, with the suggestion that no writer on Donne can afford to leave it out: "I throw myself down in my chamber, and I call in, and invite God, and his Angels thither, and when they are there, I neglect God, and his Angels, for the noise of a fly, for the rattling of a coach, for the whining of a door. I talk on, in the same posture of praying; knees bowed down; as though I prayed to God; and, if God, or his Angels should ask me, when I thought last of God in the prayer, I cannot tell. Sometimes I find that I had forgot what I was about, but when I began to forget it, I cannot tell. A memory of yesterday's pleasures, a fear of to-morrow's dangers, a straw under my knee, a noise in mine ear, a light in mine eye, an anything, a nothing, a fancy, a chinera in my brain troubles me in my prayer."

From his sermons we see that Donne held to the fundamental Christian doctrines. It has been shown that he was orthodox, but it has also been shown in Chapter II that he did not stress all the doctrines

Lynd: "The Art of Letters," p. 47-from "Donne's Sermons": Smith, p. 4. Extract from LXXX Sermons, p. 820 . 
of his Church alike. It is the natural thing for a preacher to stress the things that mean most in his own life. When one has had a great struggle before giving in to preach, as had Donne, and after being overcome, has been cormissioned and blessed in the usual way, it is natural for those things that have most vitally affected his life to be given more than ordinary places in his preaching. In the case of the one who has taken orders early in life, largely as a profession, and has had no deep experiences, there will probably be an equal stress on all the points of doctrine of the Church, but a greatly lessened vigor and power in any.

Donne had been a sinner, a great sinner in his own eyes and in the sight of God. This sin would have caused his eternal destruction but God had forgi ven his sin and assured him of salvation. But there were still in him the old desires against which he must constantly struggle, and there was a consciousness of the fact that he was still a sinner and must continually be forgiven of those sins. And so he prays:

"Wilt Thou forgive that sin where I begun,

Which was my sin, though it were done before? Wilt Thou forgive that sin through which I run, And do run still, though still I do deplore? When Thou hast done, Thou hast not done, 
For I have more.

Wilt Thou forgive that sin, which I have won

others to sin, and made my sin their door?

Wilt Thou forgive that sin which I did shun

A year or two-but wallowed in a score?

When Thou hast done, Thou hast not done,

For I have more.

I have a sin of fear that when I've spun

My last thread, I shall perish on the shore;

But swear by Thyself, that at my death Thy Son

Shall shine as He shines now, and heretofore;

And having done that, Thou hast done,

$$
\text { I fear no more." }
$$

In his sermons, Donne denounced sin with the vengeance of one who had fallen into its snare, and having paid dearly for his experience, is anxious to settle his grudge with it, but he had the ability to fight sin without abusing the sinner.

Mrs. Simpson says that "the sins which moved his contempt most were those of the selfish indolent man, who goes through life unnoved by the sufferings of others, untouched by any noble purpose, wasting his time in sloth or idle amusement, and leaves the world wi thout having accomplished any useful work to justify 
his existence. The sin of the unlit lamp and the ungirt loin was to Donne more heinous than any single crime cormitted in the heat of passion under sudden temptation, for it was the symptom of alienation from the life of God, which is endless creative activity." 1 Possibly second in emphasis was the doctrine of death. Damnation was not so much a horrible place of destruction as it was a place of separation from God, and yet Donne evinced the medieval tendency to emphasize the details of the decay and putrefaction of the grave and the worse plight of the living soul of the dead sinner. One of the most striking passages of this kind in his sermons is found in a sermon 'preached to the Earl of Carlisle, and his Company at Sion.'2 His text was Mark 16:16, "He that believeth not, shall be damned," and he closed his sermon by saying: "That God should let my soul fall out of his hand, into a bottomless pit, and roll an unremovable stone upon it, and leave it to that which it finds there, (and it shall find that there, which it never imagined, till it came thither) and never think more of that soul, never have more to do with $\mathrm{it}^{3}{ }^{3}$ that of that providence of God that studies the life of every weed, and worm,

\footnotetext{
${ }^{I}$ Simpson: "A Study of the Prose Works of John Donne," p. $7 \mathrm{~g}$.

Henry Alford: "The Works of John Donne, D. D.," vol. III, p. 386 f.

Here Alford erroneously has a period.
} 
and ant, and spider, and toad, and viper, there should never, never any beam flow out upon me; that that God, who looked upon me, when I was nothing, and called me when I was not, as though I had been, out of the womb and depth of darkness, will not look upon me now, when, though a miserable, and a bani shed, and a darned creature, yet I am his creature still, and contribute something to his glory, even in my damnation; that that God, who hath often looked upon me in my foulest uncleanness, and when I had shut out the eye of the day, the sun, and the eye of the night, the taper, and the eyes of all the world, with curtains and windows, and doors, did yet see me, and see me in mercy, by making me see that he saw me, and sometimes brought me to a present remorse, and (for that time) to a forbearing of that sin, should so turn himself from me, to his glorious saints and angels, as that no saint nor angel, nor Christ Jesus himself, should ever pray him to look towards me, never remember him, that such a soul there is; that that God, who hath so often said to my soul, Quare morieris? Why wilt thou die? and so often sworn to my soul, Vivit Dominus, As the Lord liveth, I would not have thee die, but live, will neither let me die, nor let me live, but die an everlasting life, and live an everlasting death; that that God, who, when he could not get into me, by standing, and knocking, by his ordi- 
nary means of entering, by his word, his mercies, hath applied his judgements, and hath shaked the house, this body, with agues and palsies, and set this house on fire, with fevers and calentures, and frightened the master of the house, my soul, with horrors, and apprehensions, and so made an entrance into me; that that God should frustrate all his own purposes and practices upon me, and leave me, and cast me away, as though I had cost him nothing, that this God at last, should let this soul go away, as a smoke, as a vapour, as a bubble, and that then this soul cannot be a smoke, a vapour, nor a bubble, but must lie in darkness, as long as the lord of light is light itself, and never spark of that light reach to my soul; what Tophet is not paradise, what brimstone is not amber, what gnashing is not a comfort, what gnawing of the worm is not a tickling, what torment is not a marriage-bed to this damnation, to be secluded eternally, eternally, eternally from the sight of God? especially to us, for as the perpetual loss of that is most heavy, with which we have been best acquainted, and to which we have been most accustomed; so shall this damnation, which consists in the loss of the sight and presence of God, be heavier to us than to others, because God hath so graciously, and so evidently, and so diversely appeared to us, in his pillar of fire, in the light 
of prosperity, and in the pillar of the cloud, in hiding himself for a while from us: we that have seen him in all the parts of this commission, in his word, in his sacraments, and in good example, and not believed, shall be further removed from his sight, in the next world, than they to whom he never appeared in this. But vincenti et credenti, to him that believes aright, and overcomes all temptations to a wrong belief, God shall give the accomplishment of fulness, and fulness of joy, and joy rooted in glory, and glory established in eternity, and this eternity is God; to him that believes and overcomes, God shall give himself in an everlasting presence and fruition, Amen."

And again, there was death in the simple sense of absence from the body in order to be present with God. His mind dwelt on the subject of his own death and his last sermon, preached before the King at Whi tehall on the 12th of February 1631, was on the text: (Ps. 68: 20) "And unto God the Lord belong the issues of Death (from Death)." This sermon was called Donne's own funeral sermon and it was published soon after his death with the title of "Death's Duel." And only eight days before his death, Donne wrote a poem which he called, "A Hymn to God, my God, in my Sickness." He closes this more or less geographical poem with 
the beautiful verse:

"So, in His purple wrapp'd, receive me Lord; By these His thorns, give me His other crown; And as to others' souls I preached Thy word, Be this my text, my sermon to mine own 'Therefore that He may raise, the Lord throws down.'"

Donne's next great theme was God. God's wrath is mentioned but Donne loves to dwell on the Justice of God and the Mercy of God. The two are connected. in his mind, as he says, "So that all God's Justice is but Mercy: as all our Mercy is but Justice; for ve are all mutual debtors to one another; but he to none."

In his great sermon preached at St. Faul's on Christmas day $1624,{ }^{1}$ Donne exalts the mercy of God to mankind. God began, has proceeded and will continue to proceed in $\mathrm{His}$ own ways in mercy to all mankind, and the gift of His Son was the crowning mercy of all.

In his Essays in Divinity, Donne says: "Of all these four Blements Mercy is the uppermost and most Embracing. . . His Mercy is infinite in Extent: for it is in all places; yea, where there is no place:

I" IXXXX Sermons." London 1640. Sermon II. 
And it is infinite in Duration; For as it never begun, (for the Ideating of this world, which was from everlasting, was a work of mercy) and as the interruptions vhich by acts of Justice it seems to suffer here, discontinue it not, (for though God say, 'For a moment in mine anger I hid my face from thee'; yet he adds there, 'Yet with everlasting Mercy have I had compassion on thee';) so also is it reasonable to think, that it shall never have end." I

Donne's description of heaven, and the future life of God's children called forth his best imagination and eloquence.

After the death of his wife, Donne's life became more and more secluded. He withdrew himself from almost all his former activities save his ministry, but Donne was not an ascetic. He did not hold that the body was evil, but he did exhort his hearers to overcome their evil desires, and he shoved that this could be done by usine one's energy in the service of God. His moral teachings lead not to negative, but to very positive, active Christian living. Conversion, Donne believed, is the initial step in the soul's progress to God. "In his own words, it is a turning away from our sins and a returning to-

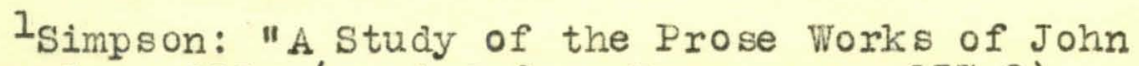
Donne," p. 211, (quoted from Essays, p. 137-9). 
ward God. It is impossible to doubt that he had himself undergone this experience." 1

Formalism could have very little place in the life or thought of a man of Donne's temperament. Sincerity meant everything to him, and if the heart was left out, worship meant very little.

God alone can truly be said to contain immortality in himself, so, to Donne the soul was immortal rather by preservation than by nature.

He believed that the Spirit of God comes into the heart of the one who is trying to serve God, and directs that one's life.

And to Donne, as to the great Apostle for whom his Deanery was named, all other things were worthless without the capstone of love in the life of the Christian. It was love that caused God to act in the redemption of man, and there must be something akin to that divine love in the heart of His servant, if he is well pleasing unto God. That love must express itself in a life that is righ with God and man, and an interest in bringing men to God, not only men who were in London, but men in all the world. In a sermon preached before "The Honourable Company of the Virginia Plantation" on the 13 th of November 1622,

ISimpson: "A Study of the Prose Works of John Donne," p. 112. 
Donne struck a very vigorous foreign missionary note when he assured those who were going to unexplored regions that their chief business was not a commercial one, but was that of giving the gospel of the Lord Jesus Christ to the lands to which they were sailing. 
CHAPTER V

DONNE'S PLACE AS A PREACHER 


\section{CHAPTER V}

\section{DONNE'S PLACE AS A PREACHER}

In order to form a correct estimate of any man, one must go behind success and failures, often the caprices of fate, to the ideals which have guided his life. Achievements largely determine a man's reputation, but motives are the true measure of character. The first thing to consider in estimating Donne as a preacher, then, is his ideals.

For the minister, Donne believed, there must, first of all, be a true call from God. I have tried to show that Donne had such a call long before he surrendered to it. In the letter which he wrote to Rochester in 1612, which has been referred to before, Donne says, "For, having obeyed at last, after much debatement within me, the inspirations (as I hope) of the Spirit of God... " " l showing that even at this time it was by no means a "sudden resolution" as Gosse says (vol. 2, p. 22), but rather a reluctant acquiescence in a long felt and much fought conviction.

"Right belief was to him of little avail without

IGosse: "Life and Letters of John Donne," vol. 2, p. 20 . 
right conduct, and right conduct meant not mere abstinence from sin but positive well-doing, a life spent in the active service of God and man."I

These ideals he held up for himself as well as for others, and the feeling of his unworthiness always kept him humble.

As to Donne's intellectual preparation for his work, there need be little said. "Poetry," Arthur Symons says, 2 "was but one means of expressing the many-sided activity of his mind and temperament. Prose was another, preaching another; travel and contact with great events and persons scarcely less important to him, in the building up of himself." He was versed in medicine, law, astronomy, physiology and geography and he is said to have left the "resultance of 1400 authors, most of them abridged and analyzed with his own hand." In poetry and in divinity Donne's library is said to have contained more books in Spanish than in English. Scientific and technical terms abound in his: sermons. He knew Oriental languages, his interests were universal and he is generally accepted, I think, as the most learned man of his generation.

${ }^{1}$ Simpson: "A Study of the Prose Works of John Donne, " p. 70 .

"Figures of Several Centuries." 1899. p. 84. 
We have already traced the steps in his spiritual preparation showing how he gradually grew from the rowdy Jack Donne of youth to the pious Dean of St. Paul's, who was so much beloved. He had known all that men experience of joy and sorrow, each to its extremity, hence his sympathies were broad.

Donne seems to have been free from the ordinary ecclesiastical prejudices. Accepting orders late in life as he did, and with no question in his or any other mind as to his intellectual equipment, possibly he did not imbibe the jealous spirit that is sometimes felt and seen in ministers. He was ambitious of advancement, but I have found no record of any bitterness towards anyone because he was not raised to a higher position, an advancement which his abilities surely warranted. His one ambition as a preacher seems to have been to live acceptably before God, by his faithfully performing the tasks that were given to him. To be sure, he had his faults, but it is an enviable compliment that this was not one of them, especially, when Brathwayte (quoted by Gosse ${ }^{1}$ ) says: "It was (Donne's) fate, I know it, to be envied as much by the clerics as he was magnified by laymen." He was tolerant, too, of those who differed wi th

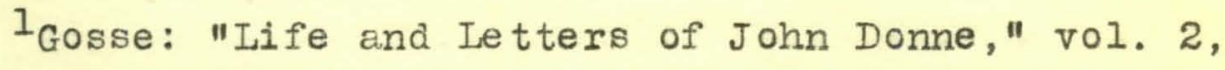
p. 235 . 
him in theological views. He wrote his "Pseudo Martyr," but it was free from hatred and bitterness, having been written from the point of view of a legal adviser to the King. "Ignatus his conclave" is a satirical series of jests and jibes written against the Jesuits, and we may not take this as his general attitude toward Catholics. Nor do I think that this work represents the spirit of Dr. Donne, the preacher, since it was written in 1611 three years before he took orders, and there is nothing of this kind in him as a minister. In his life as a minister he seems to have accepted the admonition of the Apostle Paul: "Fut on therefore, as God's elect, holy and beloved, a. heart of compassion, kindness, loveliness, meekness, longsuffering; forbearing one another, and forgiving each other, if any man have a complaint against any; even as the Lord forgave you so also do ye: and above all these things put on love, which is the bond of perfectness."l He "longed passionately," Mrs. Simpson says, 2 "for the reunion of Christiandom. He readily admitted that Rome and Geneva, as well as Canterbury, were branches of the One Church and he was troubled all through his life by the thought of

\footnotetext{
${ }_{2}^{1}$ Colossians $3: 12-14$.

2Simpson: "A Study of the Prose Works of John Donne," p. 77 .
} 
"our unhappy divisions" but this was perfectly compatible with loyalty to the Church of England."

His success in the ministry cannot be said to have been determined by politics. At once, however, we think of the fact that the king himself urged him to take orders, secured his doctor's degree for him, appointed him his own chaplain and secured his election to the deanery, and yet we see that the king refused to give him a secular place becasue as he said: "I know $\mathbb{M r}$. Donne is a learned man, has the abilities of a learned divine and will prove a successful preacher."l It was his recognized worth that secured his opportunity, and his remarkable achievements that secured his promotion and prominence.

Mrs. Simpson says of his eloquence that in conveying to his hearers the doctrines to which he gave chief emphasis, "he displays an imagination more intense and profound than that of any other English preacher. Jeremy Taylor, his only serious rival, is dwarfed not only by the greatness of Donne's style but also by the fervour of his pasion. Coleridge marked this distinction between the two men in regard to the central Christian doctrine. 'The cross of Christ is dimly seen in Taylor's works. Compare him in this respect with Donne, and you feel the dif-

$I_{\text {Gosse, vol. 2, p. } 60 .}$ 
ference in a moment.'"I

Dowden" ${ }^{2}$ says: "After he had taken holy orders Donne seldom threw his passions into verse; even his 'Divine Poems' are, with few exceptions, of early date; the poet in Donne did not cease to exist, but his ardour, his imagination, his delight in what is strange and wonderful, his tenderness, his tears, his smiles, his erudition, his intellectual ingenuities, were all placed at the service of one whose desire was that he might die in the pulpit, or if not die, that he might take his death in the pulpit, a desire which was in fact fulfilled."

Smith ${ }^{3}$ remarks: "He can pour his whole soul into his sermon, his hopes, fears, self-accusations, the furthest flights of his imagination, the ripest results of his philosophic meditations, all the wisdom of mellow experience, and even the most amusing details of satiric observation. The very circumstances of his delivery, the ceremonious solemnity of the church and pulpit, the great responsibility of the occasion, gave a nobility to his utterance; and the presence of the congregation, the need to

\footnotetext{
${ }^{1}$ Simpson: "A Study of the Prose Works of John Donne, " p. 68.

Fdward Dowden: "New Studies in Literature." $1902_{3}$ p. $90 \mathrm{f}$.

Smith: "John Donne's Se rmons," Int. xix.
} 
speak directly to the hearts and minds of men and women, lends a certain dramatic intensity to all he says."

"What gave a double force to Donne's preaching," Dr. Jessop says, ${ }^{l}$ "was, that everyone knew he had no ambition for any higher preferment-that he was giving his best to the ministry of the word-that he was laboring very much more than he was required to do. The noble earnestness of his manner, the wide sympathy and enormous learning, the sound judgernent and the lerge-hearted tolerance, won men's confidence; and the bursts of eloquence that startled his hearers so often when they came quite unexpectedly upon them, attracted crowds to listen whenever it was announced that he was going to appear in the pulpit."

"A preacher in earnest," Walton pictures him in his first sermon, 2 "weeping sometimes for his auditory, sometimes with them; always preaching to himself like an angel frorn a cloud but in none; carrying some, as St. Paul was, to heaven in holy raptures, and enticing others by a sacred art and courtship to amend their lives. . and all this with a most particular grace and an inexpressible addition of comeliness."

The tone of his preaching was not that of one who preached for popularity, but rather of one who forgot

Jessop: "Life of John Donne," p. $185 f$. Walton's "Lives"--John Donne, p. 48. 
himself while bringing what he believed was a message of God to his people. His earnestness knew no selfish thought when he said: "What sea could furnish mine eyes with tears enough, to pour out, if I should think, that of all this congregation, which looks me in the face now, I should not meet one, at the resurrection, at the right hand of God! And for so much as concerns me, it is all one, if none of you be saved, as if none of you be saved by my help, my means, my assistance, my preaching. . . When at any midnight I hear a bell toll from this steeple, must not I say to myselfe, what have I done at any time for the instructing or rectifying of that man's conscience, who lieth there now ready to deliver up his account, and my account to Almighty God?"I

"Donne was a great preacher," says Mrs. Simpson, 2 "because he insisted on raising his audience to his own level by the intensity of his spiritual passion. His, individual as it was in its personal apprehension of God, was also emphatically social. He would not be saved alone; he stretched out imploring hands to the men and women who were sinning as he had sinned, but

I From first sermon preached as vicar of St. Dunstan's. 1lth April, 1624. "The Works of John Donne, D.D. " Henry Alford, vol. V, p. $259 \mathrm{f}$. 2Simpson: "A Study of the Prose Works of John Donne," p. 65 . 
who were also potential members of the Communion of Saints."

Donne's ability and popularity as a preacher would naturally have advanced him in the church, and it is a matter of surprise to us that he was not given a higher position. Gosse thinks that very likely Donne's connection with the shameful Rochester marriage was the thing that prevented his advancement. We know that as soon as he had definitely committed himself to the ministry and had received from the king as good allowance as his expensive journey to Newmarket, Donne wrote to his father-in-law hoping to obtain the good graces of George Abbot, Archbishop of Canterbury. Abbot had not been pleased by somerset (Rochester), and there is evidence that they were not on pleasant terms at this time. Gosse says: 1 "I have a suspicion that it was the opposition of the Archbishop which delayed Donne in rising to those dignities in the Church which his talents and the favour of two monarchs would naturally have demanded. No one took to heart more profoundly than Abbot the shame and horror of the somerset marriage, and I think that he would consider that the man who had laboured to collect evidence on the side of Lady Essex, and

IGosse: "Iife and Ietters of John Donne," vol. 2, p. 62 . 
had composed an epithalamium for those hideous nuptials, could never be a bi shop of the Church of England." Of course Donne's connection with the case was only as a legal adviser, and this long before his taking orders, but the fact of his connection with the case in any way was enough to prejudice Abbot. I have shown in the first chapter he was about to receive advancement anyway when his final illness and death occurred.

To say that Donne's sermons are interesting today would be going a bit too far. They are filled with the old theology, with medieval coloring and are very dry and boring dissertations on subjects which have long since been forgotten. However, here and there are to be found passages of rare beauty. From the smoldering embers there occasionally bursts forth a flame that brightens and warms and cheers all about it. But the audience of his own day found him interesting enough to come in great crowds whereever he preached. There is evidence that there were some in his audiences at times who did not give him their attention, some in sleeping, others in creating disturbance, but there was doubtless less of this in his than in other congregations. "The popularity of Donne as a preacher rose to its zenith in 1626, and remained there until his death in 1631. During those 
years he was, without a rival and the nost admired religious orator in England. . . Age gave to the fiery and yet sombre Dean of St. Paul's an ever increasing majesty of prestige. His hearers, borne along upon the flow of his sinuous melody, now soft and winning, now vehement in storm, now piercing like a clarion, now rolling in the meditative music of an organ, felt themselves lifted up to heaven itself. In these early days of Charles I a sermon deli vered by the Dean of St. Paul's was the most brilliant public entertainment which London had to offer." I

Dr. Jessop says: 2 "When the year 1627 opened there was only one prominent divine in England who can in any sense be called a great preacher; and that one was the Tean of St. Paul's." He goes on to show that "Donne as a preacher stood above. It was said of him that he was always growing more impressive and more eloquent as he grew older-the truth being that he becme ever more and more absorbed in the duties of his sacred office, throwing his whole heart into it, rising to every occasion on which demands were made upon him, always doing his best as an enthusiast with a mission, who felt that he would have to give account for the talent that was committed to him."

\footnotetext{
${ }^{I_{\text {Gosse: }}}$ "Life and Letters of John Donne," vol. 2., 2. 234. "Jessop: "Life of John Donne," p. $183 \mathrm{f}$.
} 
Mrs. Simpson ${ }^{1}$ concludes that "Donne was not a great speculative or constructive theologian. His sermons are the work of an orator, a poet, and a mystic, whose strength lay in the reality of his own personal religious experience and in the power of imagination by which he bodied forth things unseen and made them almost visible to his hearers. As a controversialist, his work was generally marked by moderation and restraint, but he was happiest when he could escape from the mists of theological disputes into the clear air of faith and devotion. His loyalty to the Anglican Church has sometimes been called into question, but there is no reason to doubt his sincerity on this point. At the same time he never showed the peculiar love for the Bnglish Church which distinguished his intimate friend and political disciple, George Herbert, who dwelt fondly on every detail of its order and ceremonies. Donne's eyes were fixed on a wider vision of one great united Christian Church, and the divisions of Christendom vexed his soul as they never vexed Herbert's. His devotion was given, not to any one branch of the Church, but to the $i$ deal figure of the Bride of Christ who should one day be revealed with her torn and

${ }_{\mathrm{E}}$. M. Simpson: "A Study of the Prose Works of John Donne," p. 86 f. 
soiled garments replaced by the stainless robe of perfect unity."

". . We that heard him, to ourselves did faine Golden Chrysostorne was ali ve again."l

"Such was thy carriage, and thy gesture such, As could divide the heart, and conscience touch. Thy motion did confute, and wee might see An error vanquish'd by delivery.

. . In such temper would thy sermons flow, So well did Doctrine, and thy language show, And had thy holy feare, as, hearing thee, The Court would mend, and a good Christian bee," 2

If the business of the preacher is to know God and to bring a true knowledge of God to men, then John Donne deserves the name, and his devotion to and success in his task have earned for him a worthy place in the galaxy of servants of the Christ in all ages.

$1_{R}$. Busby: "In Memory of Dr. Donne, "Quoted in full in Simpson: "A Study of the Prose Works of John Donne, " p. 239 f. p. 240 .

Jasper Hayne: "On Dr. Donne's Death." Simpson, 
CHAPTER VI

DONINE'S PLACE IN IITERATURE 


\section{CHAPTER VI}

\section{DONNE'S PLACE IN LITERATURE}

In the field of poetry, Donne's works consist of satires, epistles, elegies, religious poems, and epigrams. Satire was his first choice, and Donne is probably second only to Lodge in point of time in Bnglish satire, Joseph Hall, whose works were published first of the three, being third. But it seems certain that Donne was not aware that others were attempting the same thing, hence he may be considered a pioneer in the field.

His satires (there are seven in number) are important because of their beauty and force, as well as their priority. In satire VI he says:

Men write that love and reason disagree,

But I ne'er saw it exprest as 'tis in thee,

We11, I may lead thee, God must moke thee see;

But thine eyes blind too, there's no hope for thee.

Thou sayst she's wise and witty, fair and free; All these are reason why she sinould scorn thee." There are many places in his satires, however, as well as in his other poetry, where Donne has so succeeded in veiling his thought that one reads and un- 
derstands as one on the borderland between consciousness and unconsciousness. Those lines which are clear, however, strike home with great force, and often combine deep though with beautiful construction.

There are thirty-six of his epistles recorded in the 1781 edition of "The Foetical Works of Dr. John Donne," British Poets series. These were written to various people with whom Donne was intimate, and they give us an insight into Donne's friendships. They often sparklewith humor (e. g., "The storm") and rare bits of Donne's philosophy are to be found in them, for example:

"Reason is our soul's left hand; Faith her right; By these we reach divinity. . . ."

("To the Countess of Bedford.")

While at the home of Lord Thomas Egerton, Donne began his "The Progress of the Soul," with the purpose of writing, as Gosse says, "a metaphysical narrative in verse in a manner which should remind his readers of no previous work." I After writing some five hundred lines, Donne quit work on it. It is very sensuous and un-Christian, and in his later life Donne wished it destroyed.

Of his Divine Poems, perhaps his Holy Sonnets are

$I_{\text {Gosse: }}$ Life and Letters of John Donne," vol. 1 , p. 131 . 
the most important. There are twenty-six of these arranged in the regular style of three quatrains and a couplet, but, while they contain some remarkable poetry, not one of them can be considered faultless.

Among his miscellaneous poems, songs and sonnets, some of the most important are: "Loves Growth," one beginning:

$$
\begin{aligned}
& \text { "Sweet Love, I do not go } \\
& \text { For weariness of thee," }
\end{aligned}
$$

"The Undertaking," "A Valediction Forbidding Mourning," one beginning:

"Go and catch a falling star . . . ," "Lover's Infiniteness," "The Dream," and "Loves Deity." As poets, Donne and Browning have often been considered the only two in English literature who stand without ancestors. "Donne would be original at all costs," says Symons, 1 "preferring himself to his art. He treated poetry as Aesop's master treated his slave, and broke what he could not bend."

of Donne as a satirist, The Cambridge History of English Literature ${ }^{2}$ says that he $"$ is, whether actually the first in time or not, the first who deserves attention, the first whose work is in the line of later

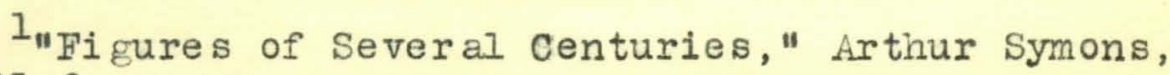
p. 95 f.

${ }^{2}$ Vol. IV, p. 227 .
} 
development, the only one of the sixteenth century satirists whose influence is still traceable in Dryden and Pope. "Religio Laici" is indebted for some of its most characteristic arguments to Donne's "kind pity checks and spleen"; and Pope found in Donne a satirist whose style and temper were closer in essential respects to his own than those of the suave and urbane Horace." In the same work, ${ }^{1}$ Donne is called "the poet who challenged and broke the supremacy of the Petrarchian tradition. . . With Donne begins a new era in the history of the English love lyric, the full importance of which is not exhausted when one recognizes in Donne the source of the 'Metaphysical' lyric as it flourished from Carew to Rochester."

Among Donne's immediate followers in poetry may be numbered Henry King, George and Edward Herbert, Richard Corbet and Jasper Mayne. All these accepted and followed Donne in his lifetime.

Crashaw was the most illustrious of his indirect followers, according to Gosse's estimate. 2 And of Dryden, he says, 3 "No one who studies that remarkable and now neglected poem, the "Annus Mirabilis," can fail to notice the paramount prestige which Donne ex-

IThe Cambridge History of English Literature, vol. IV, 2 Gosse: "Life and Letters of John Donne," vol. 2, p. $3 \frac{47}{3}$.

Ibid, vol. 2, p. 349 . 
ercised over the youthful mind of Dryden. . . . The weight of the lives, the intensity which the writer endeavors to press into them, the violence and startling nature of the illustrations, and, above all, the constant reference to images essentially modern and realistic, all this is due to no other model than Donne." Gosse goes on to say that direct traces of imitation of Donne, in the verse of Dryden, disappear after 1667. Dryden once called Donne "the greatest wit, though not the best poet, in our nation."

If we are to accept Ben Jonson's judgment that "all his best pieces were written ere he was twenty-five years old," the years 1593-1598 were his best years as a lyrical poet.

Gosse ${ }^{l}$ sums up Donne's innovations in poetry as, first, a redundancy of intellectual suggestion. "The Elizabethan poet had held up a mirror to nature; Donne . . shivered the glass, and preserved a reflection from each several fragment." Second, the absence of all conventional or historical ornament. He draws his illustration from chemistry, medicine, law, mechanics, astrology, religious ritual, daily human business of every sort."

There is no record of Donne's associating with

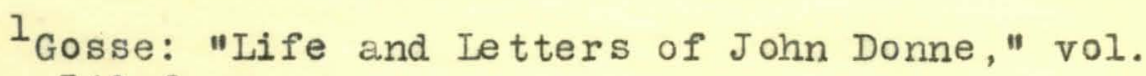
2, p. 340 f. 
any of his poet contemporaries save Ben Jonson who considered him "the first poet of the world in some things." Of Drayton, who was intimately connected with the household of Donne's friend, Sir Henry Goodyer, there is nothing said at all, and the same silence greets us with reference to Samuel Daniel, with whom Donne was, wi thout doubt, acquainted.

In estimating Donne's position as a poet, "The Cambridge History,"l says: "For evil and for good, Donne is the most shaping and determining influence that meets us in passing from the sixteenth to the seventeenth century. In certain aspects of mind and training the most medieval, in temper the most modern, of his contemporaries, he is, with the radically more pedantic and neo-classical Jonson, at once the chief inspirer of his younger contemporaries and successors, and the most potent herald and pioneer of the school of poetic argument and eloquence."

of Donne's prose works, "Juvenilia," or "Paradoxes and Problems," comes first, but its exact date is not known. There are eleven paradoxes dealing with such subjects as "A Defence of Women's Inconstancy," "That Women ought to Paint," and "That only Cowards

1 The Cambridge History of English Literature," vol. IV, p. 227. 
dare Dye"; and ten problems which are generally shorter than the paradoxes, but have largely the same tone of cynical levity. Donne was apparently ashamed of the se long before his ordination. 1

"Biathanatos" was likely written, as I have shown in Chapter I, in 1608, when Donne's outlook on life was very discouraging. The book is divided into three parts. In the first part, he argues that suicide cannot always be said to be against the 1 aw of nature, because the law of self-preservation ought to be broken at times, as in the case of the pelican which sacrifices itself to feed its young. In the second part he deals with the civil and canon laws concerning suicide; and in part three he considers the Law of God, admitting that the Sixth Commandment is a general prohibition of the act.

"Pseudo-Martyr" was written in 1609, and was published in 1610, the first of his prose works to be printed. In this work, Donne's quarrel with the Roman Church is over the question whether Catholics should take the Oath of Allegiance. He does not go into the

l"Juvenilia," "Biathanatos," "Pseudo-Martyr," "Ignatius his Conclave," and "Esays in Divinity" have not been available in my studies except in excerpts in treatises on Donne's works. Hence, my estimates are largely based on the conclusions of others. 
tenets of Rome, but the burden of his proof is that those who suffer for refusing to take the oath are not martyrs at all. He holds that all self-sacrifice is not virtuous, and if in vain and erroneous, it may become sinful and suicidal. In the closing words of his preface Donne rises to something of the eloquence of the future Dean of St. Paul's as he pleads with those who hold to the Catholic faith, remembering them with his own soul in prayers "that your obedience here may prepare your admission into the heavenly Hierusalem, and that by the same obedience, your days may be long in the land which the Lord your God hath given you. Amen." 1

The fourth of Donne's prose works, "Conclave Ignatii" or "Ignatius his Conclave," written in 1611, is a series of squibs composed of "bitter jests and skirmishings" aimed at the Jesuits. In this satiric work Donne imagines himself in a dream visiting the lower regions, and there he sees Ignatius acting as chief adviser to Lucifer, and intriguing to hold his position.

Donne's "The Essays in Divinity" was probably written in 1614 or 1615 , and was published in 1651.

IFrom an excerpt from "Pseudo-Martyr" given by E. M. Simpson: "A Study of the Prose Works of John Donne," p. 177 . 
Gosse calls this "the least attractive of Donne's published. works."

The "Devotions upon Hmergent Occasions" were compiled during Donne's dangerous illness in the winter of 1623 and printed in 1624. "In the se the rich sustained eloquence of the 'Sermons' is lacking, but in other respects the prose of these 'Devotions' shows the unusual features of Donne's style-the brilliant display of metaphysical wit, with its far-fetched allusions and similes, the immense amount of learning of all kinds, the delight in the paradox, and the passionate sincerity which gives life to even the most fantastic exercises of Donne's intellect." I

There are about two hundred of Donne's letters available to-day. They are important in giving us an understanding of Donne's character, and yet they are far from being as intimate as one would like. They do not hold the place in literature that the letters of Cowper and Lamb do, nor are they equal in prose value to some of Donne's other works.

Donne's Sermons have already been considered and it only remains to give their value as prose literature. Mrs. Simpson sums up several opinions in saying that "the value of his other works is largely his-

${ }^{1}$ Simpson: "A Study of the Prose Works of John Donne," p. 226. 
torical and antiquarian; it is in virtue of the 'Sermons' that he takes his place among the greatest masters of English prose. 'They are as unlike any other sermons as his poems are unlike any other poetry,' sald Charles Eliot Norton, and this judgment is but the echo of earlier and greater critics, such as Coleridge, who was a lover of Donne and once asked, 'Why is not Donne's volume of sermons reprinted at Oxford?'"I

"Donne's fame as a prose writer rests... on his sermons. His reputation as a preacher was, probably, wider than as a poet, and both contributed to his most distinctive and generally admitted title to fame as the greatest wit of his age, in the fullest sense of the word." 2

I have not tried to picture Donne as fautless. His life, his poetry, his prose writings and his sermons are all full of faults, flaws of construction in his poetry, improprieties in his life, obscurity of thought and sensuality. And yet, with every fault there is an over-balancing virtue which

I . M. Simpson: "A Study of the Prose Works of John Donne," p. 234, quoting "Table Talk," i. 168 (1835 edition).

2 "The Cambridge History of English Literature," vol. IV, p. 251. 
grips and keeps our interest. "Splendid and obscure he was," Gosse concludes, 1 "in the extreme versatility and passion, the profundity, the saintliness, the mystery of his inscrutable character. No one, in the history of English literature, as it seems to me, is so difficult to realise, so impossible to measure, in the vast curves of his extraordinary and contradictory features. . . He was not the crystal-hearted saint that Walton adored and exalted. He was not the crafty and redoubtable courtier whom the recusants suspected. He was not the prophet of the intricacies of fleshly feeling whom the young poets looked up to and worshipped. He was none of these, or all of these, or more. What was he? It is impossible to say, for, with all his superficial expansion, his secret died with him. We are tempted to declare that of all great men he is the one of whom least is essentially known. Is not this, perhaps, the secret of his perennial fascination?"

In speaking of the friends of Sir Henry Wotton, Izaak Walton ${ }^{2}$ says: "Yet I must not omit the mention of a love that was there (at Oxford) begun between

$I_{\text {Gosse: }}$ "Life and Letters of John Donne," vol. 2, ${ }^{2} \begin{aligned} & 290 \\ & 2_{W a l t o n}\end{aligned}$ Londion ex. p. 134. 
him and Dr. Donne, sometime Dean of St. Paul's; a man whose abilities I shall forbear to say anything, because he who is of this nation, and pretends to learning or integrity, and is ignorant of Dr. Donne, deserves not to know him." 
BIBIIOGR APHY 


\section{BIBLIOGRAPHY}

"IXXXX Sermons." London. 1640.

"X Sermons."

"Donne's Sermons, Selected Passages." Pearsall Smith Oxford. 1920.

"The Works of John Donne, D. D." Henry Alford. 6 vol. 1839.

"A Study of the Prose Works of John Donne." Evelyn

M. Simpson. Oxford 1924.

"Lives of John Donne, Henry Wotton, etc." Izaak

Walton. London. 1898.

"Life and Letters of John Donne." Edmund Gosse. 2 vol. 1899.

"John Donne." Augustus Jessop. 1897.

"The Cambri dge History of English Literature." vol. IV. "Dictionary of National Biography." vol. XV.

"A Library of the World's Best Literature." vol. XII.

Charles D. Warner, Editor.

"Figures of Several Centuries." Arthur Symons. 1899.

"The Art of Letters." Robert Lynd. 1921.

"Fnglish Frose." Henry Craik. vol. II.

"New Studies in Iiterature." Edw. Dowden. 1902. 
"British Poets, Donne." Jas. R. Osgood \& Co. pub. Boston. 1871.

"A Book of Elizabethan Lyrics." Felix E. Schelling. "Preparation and Delivery ol Sermons." John A. Broadus. 